\title{
A STUDY ON THE ROLE OF TECHNOLOGY/AUTOMATION IN STOCK MARKETS AND BANKING
}

\author{
Mayank Kataria \\ ORCiD : https://orcid.org/0000-0002-6083-0052 \\ Student, Lotus Valley International School, Gurgaon, HR, India \\ DOI: 10.46609/IJSSER.2021.v06i07.005 URL: https://doi.org/10.46609/IJSSER.2021.v06i07.005
}

\begin{abstract}
Technology and automation have been continuously adopted by stockbrokers and banks - two key participants of the financial services industry. The adoption was to reduce costs and improve productivity. Increasing digitization, ubiquity of the mobile phone and easy internet access are key trends that are now shaping all industries and financial services is no exception. New, digitally native, consumer satisfaction obsessed companies like Google and Apple are keen to enter \& disrupt the traditional players. A whole new "FinTech" industry has taken shape globally in the past decade. The study was conducted to focus on the traditional players of the banking and stock market ecosystems and get insights on how mass technology adoption can help existing players stay relevant through increased customer satisfaction. The author analyzed a broad spectrum of data of leading industry players from two diverse markets - India and the United States. The findings from multiple global consultancies were delved into, thereby making this a comprehensive, novel and globally oriented collaborative study. The key positive takeaways for the incumbents was that they enjoyed the advantage of larger scale and trust built over the decades. However, this study also confirmed that new age players were challenging, quite successfully, the established players in domain after domain. The implications for incumbents was clear - requirement of massive technology investment and process redesign to stay relevant in this industry. The research hypothesis stated that there is a significant change in variables such as cost and customer satisfaction, after implementation of automation and technology; and it has been accepted.
\end{abstract}

Keywords: Automation, Banking, Stock Market, Technology

\section{INTRODUCTION}

Technology has been continuously used in the finance world. The finance industry adopts new and reliable technology in a jiffy, since it helps in drastically reducing their costs and improving productivity. Ever increasing digitization, availability of mobile phones and easy internet access 
are some of the things that are now shaping all industries, with finance being no exception. New, digitally native and consumer satisfaction obsessed companies like Google and Apple are keen to enter \& disrupt the traditional players. The study was conducted to focus on the traditional players of the banking and stock market ecosystems and get insights on how mass technology adoption can help existing players stay relevant through increased customer satisfaction and increased profitability.

\section{Definition of Technology}

- Technology refers to methods, systems, and devices which are the result of scientific knowledge being used for practical purposes.

\section{Definition of Automation}

- The creation and application of technology to monitor and control the production and delivery of products and services.

\section{Definition of Stock Market}

- A stock exchange is a marketplace, where financial securities issued by companies are bought and sold.

\section{Definition of Banking}

- "Banking" means the accepting, for the purpose of lending or investment, of deposits of money from the public, repayable on demand or otherwise, and withdrawal by cheque, draft, order or otherwise.

\section{CONCEPTUAL HISTORY}

\subsection{Stock Market}

The initial joint-stock companies were formed in the late 1600s, issuing shares to finance their ventures. Balen (2002) documented the story of the first financial crisis, the South Sea Bubble. The primary mode of communications for the financial markets were teams of horse-riding messengers. Traders with the best horses had the most current information. Then, the now international news organisation Reuters, used carrier pigeons to relay messages over long distances with greater efficiency.

The absence of dependable, extended communications technology meant trading establishments and banks needed to have their offices present geographically close to the main exchanges. This 


\section{International Journal of Social Science and Economic Research}

ISSN: $2455-8834$

Volume:06, Issue:07 "July 2021"

brought about nests of financial establishments in major cities such as those around Wall Street in New York, The City or Canary Wharf in London, and Dalal Street in Mumbai .

During the late 1900s, came the arrival of the telegraph and telephone. Fixed-line communication, along with printed paper, was the dominant enabling technology of the financial markets for the first 70 years of the twentieth century. In the 1980s, Michael Bloomberg introduced the Bloomberg Terminal; a computer based information system that used large screens linked to computers.

The advent of the personal computer in the late 1980s was a game changer as it could be programmed to issue electronic orders directly to the markets. As the cost of this technology steadily reduced, management of funds became increasingly technical, which had its own disadvantages. The Black Monday crash (October 19, 1987) and collapse of the Long Term Capital Management (LTCM) hedge fund in September the next year, hurt confidence in automated trading systems.

The birth of the internet led to new web-based marketplaces and exchanges. Technologyconcentrated Electronic Crossing Networks (ECNs) started to operate online exchanges. This new era of automation concentrated on the execution of a trade: the computer did not make the decision to buy or to sell shares or commodities, but, once the decision had been made by individuals, the execution was done by automated execution systems (AES). This freed human traders to deal with other tasks. As AES became increasingly trustworthy, trading institutions started to experiment with different methods, and algorithms, which could be deployed to fit the needs of different types of transactions, under varying market conditions; and hence the concept of algorithmic trading came into existence.

In 2014, more than 75 percent of the stock shares traded on United States exchanges (including the NYSE and NASDAQ) originated from automated trading system orders.

In the 2000s, advancements in computational infrastructure led to a host of innovations for the stock market. Some of the most important of these innovations include Straight-Through Processing (STP), which is an automated process done purely through electronic transfers without human interference; and Direct Market Access (DMA) which refers to access to the electronic facilities and order books of financial exchanges that facilitate daily securities transactions. In the late 2000s and early 2010s, these have been joined by Smart Order Routing (SOR), where orders to buy or sell are automatically routed to the exchange or ECN that offers the best price for that order. Recently, High-Frequency Trading (HFT) has emerged, where automated systems buy and sell on electronic exchange venues, often holding a particular position for only a few seconds; meaning an HFT system might 'go long' by buying shares, hold 
International Journal of Social Science and Economic Research

ISSN: 2455-8834

Volume:06, Issue:07 "July 2021"

for two to three seconds, and then sell it to a buyer. If the price of the share increases in those three seconds, and so long as the transaction costs are miniscule, the HFT system makes a profit on the trade.

\subsection{Banking}

In 1871, Western Union introduced the first ever wire-transfer of money using the existing telegram technology. Wire transfers provided the ease of same-day transactions, and were an immediate sensation with the public. Although the first documented use of cheques can be dated way back to the 11th century, the first proper cheques came about only in 1910 when the American Bankers Association implemented routing numbers on cheques to allow universal processing. Cheques are becoming obsolete though, there has been a drop in transactions with cheques by about $60 \%$ in the years between 2000 and 2015, falling from 43 billion to 18 billion transactions in the United States.

Another 4 decades later, the latest innovation in banking was the credit card when the Diners' Club was launched. At the time the card could only be used at 14 eateries in New York, but fast forward to 2015, the global number of transactions each year stands at close to 400 billion.

Soon enough, another wave of innovation was brought about when the Automated Teller Machine (ATM) was introduced in the late 1960s. After the introduction of ATMs, the new technology kept coming at a pace faster than ever. In the early eighties, banks started experimenting with Internet Banking, with the first bank website being released in the early nineties. Then we had the EMV Chip technology, a system that connects a small chip in a credit or debit card to a payment terminal. The chips stored confidential information in a secure way to help reduce fraud and could process payments either by contact or, even by waving the card close to the payment terminal.

The first two decades of the 21 st century were riddled with even more enhancements in banking technology. The launch of smartphones in 2007, starting with the iPhone, introduced mobile applications to the common public, which became a common avenue for banks to reach their clients with mobile banking applications. The 2010s also gave us the mobile and peer-to-peer payments, hence further making it easier to disburse payments. 


\section{International Journal of Social Science and Economic Research}

ISSN: 2455-8834

Volume:06, Issue:07 "July 2021"

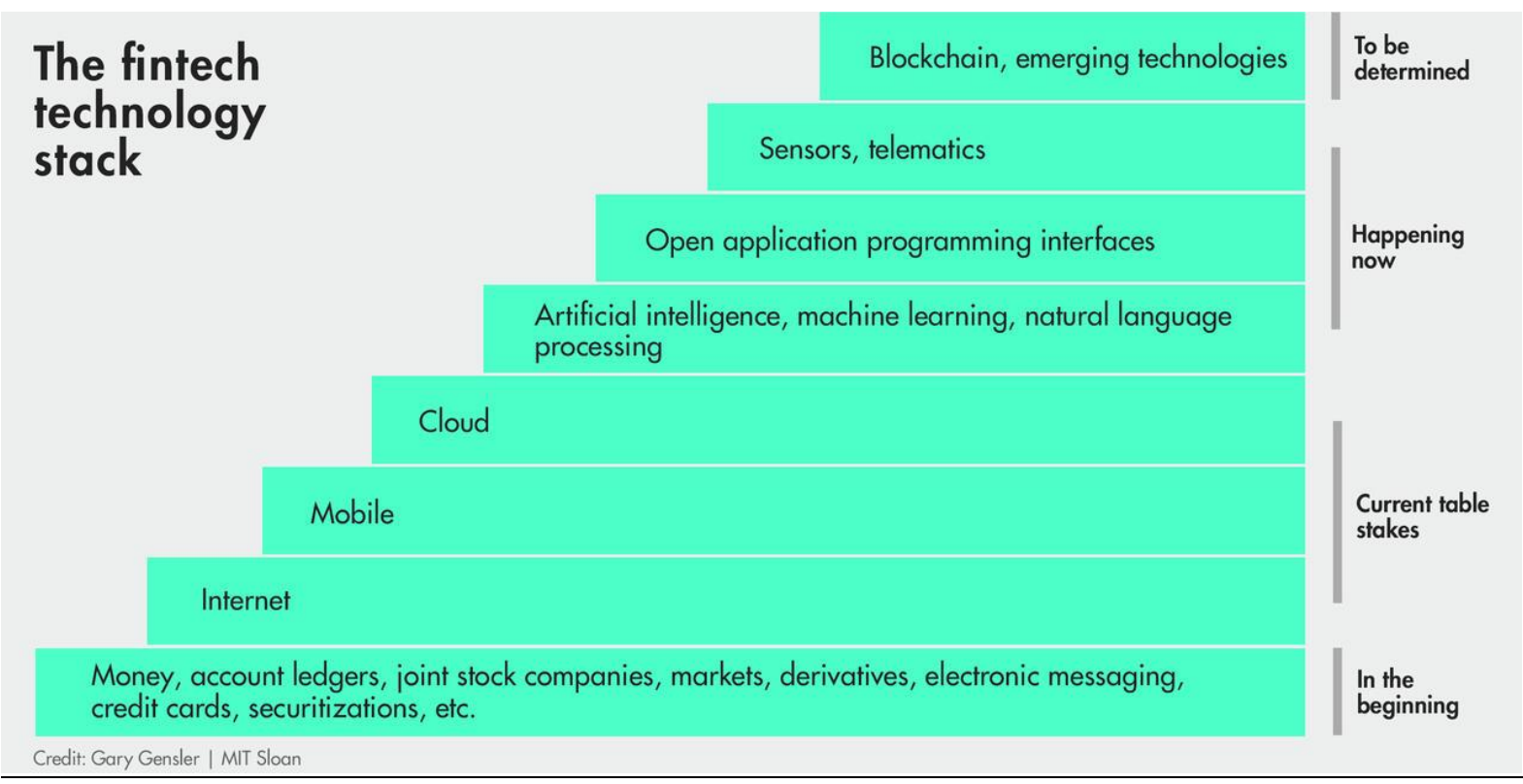

Fig 1 : Timeline of the Applications of Financial Technology.

\section{The evolution of customer interfaces in finance}

Contactless and cardless systems (2000s)
Mobile payments (2000s), mobile wallets (2008)
Internet banking (1990s), online banking (1990s - 2000s)
Automatic teller machines (1970s)
Credit cards (1940s - 1950s) and point-of-sale systems (1980s)
Electronic payments (1870s), wires (1910s), automatic clearing houses (1970s),
direct deposits (1970s)
Checks (800s), negotiable checks (1500s), preprinted checks (1760s)
Banking tents, temples, bricks and mortar (4th - 1st millennium BCE)
Credit: Gary Gensler | MIT Sloan

Open banking, open application programming interfaces (2015) Chatbots, conversational interfaces, voice assistants (2010s)

21 st century

20th century

Pre-20th century

Fig 2 : Evolution of direct-consumer interface in Financial Technology. 
International Journal of Social Science and Economic Research

ISSN: 2455-8834

Volume:06, Issue:07 "July 2021"

\section{REVIEW OF LITERATURE}

\subsection{Stock Market}

Technology has had a deep impact on our lives and is generally regarded to have enhanced the quality of our social lives, businesses, governments and education. Unless one isa broker or investor, not much heed is paid to the impact that technology has had on the productivity of The Stock Market. The success of stock exchanges have had a positive influence on the economies of their respective countries.

\section{The Rise of The Dot Com Companies}

The jump in the use of the internet in the 1990s caused a surge of websites involved in selling products or services online. These companies didn't always profit but concentrated on building up traffic to their websites and better connectivity. As connectivity to the internet grew, venture capitalists became interested in investing in what they saw as the future market. In 1999 many dot.com companies such as 'lastminute.com' and 'boo.com' were able to offer IPOs at high prices because of all the exposure they had. Stock exchanges were abuzz with these new exciting flotations. Choosing the path of "growth over profit" requires immense amounts of capital and it wasn't long before what is referred to as the 'dot com bubble' started to burst. Today virtually everyone has access to the internet, but back then not so many people owned PCs and there was mistrust about buying online. 'Boo.com' was one of the companies to go into receivership after spending over $£ 100$ million in just 6 months. Ernst Malmsten founder of Boo.com said later "The internet was new back then: we were the pioneers. Today the technology is so accessible."

Lastminute.com along with Amazon and Google managed to stay afloat despite their share prices plummeting in the burst by riding the storm. Many people believe that all the speculation around the dot com bubble helped create the internet we have today.

Jeff Bezos, Founder and CEO, Amazon said of that time: "Because, you know, resilience - if you think of it in terms of the Gold Rush, then you'd be pretty depressed right now because the last nugget of gold would be gone. But the good thing is, with innovation, there isn't a last nugget. Every new thing creates two new questions and two new opportunities."

\section{Manipulation of Markets through Social Media}

The long held belief that 'Any publicity is good' isn't always the case when it comes to Social media campaigns. Misinformation such as rumours of a fall in a company's stock price or even as in the case of Qantas in 2010 when a false rumour on Twitter about a plane crash caused their stock to fall. Sometimes positive rumours about a company are started deliberately to start 


\section{International Journal of Social Science and Economic Research}

ISSN: $2455-8834$

Volume:06, Issue:07 "July 2021"

investors buying shares that push the prices up which can then be sold to make a profit for the masterminds who bought them at very low rates. This practice is referred to as "Pump and Dump". There was the recent example of rapper 50 cents, whose use of twitter to tell his followers about an excellent opportunity, caused the price of a penny stock he had invested in to increase dramatically making him millions of dollars profit. (Not implying that he caused the rise deliberately of course).

Recently, GameStop, due to a rise in competition and decline in foot traffic at malls, became a target of short-sellers. The short interest had grown to over $100 \%$ of the shares outstanding. Then a bull case for the company - that it could return to profit in a couple of years - started getting around in early 2021. The bull case was also touted on Reddit. As well, big investors, such as Scion Asset Management's Michael Burry and Chewy co-founder Ryan Cohen, also took a long position. From there it was a snowball effect of retail investors buying stock and call options. The price increase drove out some short-sellers and attracted various big-name investors and public figures, such as Elon Musk and venture capitalist Chamath Palihapitiya. GameStop's stock price surged due to a short squeeze on major hedge funds that were short the stock and forced to sell to cut losses. The stock price went from less than $\$ 5$ to $\$ 325$ a share (January 2021) in less than six months. The stock currently trades at around $\$ 185$ per share.

We are all subject to digital manipulation and a recent survey in the UK has shown that $62 \%$ of individuals involved with the stock market believe that social media sentiment influences share prices.

\section{Electronic Trading}

Information Technology is all about calculations and data and so is Stock Trading, it was an inevitable match that increased efficiency and organisation. Today the high speed computers used by traders can broker a deal in nanoseconds much quicker than a human. The introduction of Algorithms into the markets has revolutionised the way stock brokers decide what stocks to buy and sell. Algorithm Trading uses computer programmes that follow certain instructions to calculate chart patterns in order to make safe investments.

Along with the benefits there also are fraudsters manipulating the price of stocks. In April 2015, Commodities trader Navinder Singh Sarao was arrested at his home in London in connection with the 2010 "Flash Crash" that rocked global markets. According to the Commodities Futures Trading Commission, Sarao spoofed S\&P futures, called "E-Minis," from 2010 to 2014 by layering algorithms. These are electronically traded futures contracts that represent a percent of a corresponding standard futures contract. 


\section{International Journal of Social Science and Economic Research}

ISSN: $2455-8834$

Volume:06, Issue:07 "July 2021"

Alongside high speed predictions, other ways through which technology has impacted stock trading includes websites and online newspapers which report immediate news on takeovers and prices enabling traders to make more informed choices.

It is clear that exchanges will continue to evolve more and more sophisticated ways of dealing as technology continues to advance. Big Data will be used for analysing market psychology. But, despite the success of automated trading, the human element will continue to be needed in the process.

\subsection{Banking}

Retail banks currently operate in a customer-driven era, where customers choose their financial services supplier based on countless factors such as speed, personalisation and flexibility. Thus, banks have adapted their delivery channels in order to reach more customers and provide a wider range of services and products. Technological innovation plays the most prominent role in the creation of these delivery channels. These innovations. in the last two decades, led to large scale digitization of banking and payments systems.

\section{Bank Branches}

Bank branches offer a broad spectrum of face-to-face services, such as bank account inquiries, monetary payments and transfers, personal and mortgage loans, securities, and cheque cashing. Many branches are also equipped with vaults and cash safes. A bank branch is the oldest and most traditional way of delivering services to customers. As banks used to work in an analog way, bank branches were the only way banks could offer their services. From a risk point of view, a branch is considered the most secure due to the direct identification of the customer (Pond, 2017). However, in recent years, branch visits have dropped by significantly, while the use of mobile and internet-enabled banking has risen correspondingly. It is estimated that a faceto-face transaction at a branch costs approximately $\$ 4.24$, while the same operation done through mobile banking costs roughly $\$ 0.10$ (Nicoletti, 2014). Today, banks face fierce competition from new-age digitally-focused banks to reduce their costs, which results in a global reduction of the branch network (Bizle, 2007).

\section{Phone Banking}

Retail banks use dedicated call centres to provide services such as account requests and execution of fund transfers. The purpose of phone banking is to replace a branch visit by having a $24 \times 7$ service just by dialling a number. The main difference between the branch banking and phone banking is the identification process. To overcome this issue, banks introduced phone banking passwords; such as a keyword, security question or number that consumers set. Usually, 
International Journal of Social Science and Economic Research

ISSN: 2455-8834

Volume:06, Issue:07 "July 2021"

call operators only ask for a part of the password to eliminate the risk of someone overhearing the full password.

\section{Internet Banking}

During the 1990s, after the boom of the World Wide Web and the introduction of Web 2.0 with its supplementary functions, banks such as Wells Fargo and ING started offering a new service to the consumers' home computers called Internet banking, which allowed consumers to access their accounts using the bank's secure website and perform tasks at home. Today, increase in the usage of the Internet has made Internet Banking evolve into a sophisticated system where customers can perform the majority of tasks that were earlier only possible before through a branch.

\section{Mobile Banking}

Mobile banking operates similarly to internet banking, but it utilises the usage of portable devices such as smartphones or tablets. The mobile banking sector is seeing both financial and non-financial entrants such as FinTech companies, BigTech (Facebook, Paypal, Google, Apple), and telecommunication companies, among others. The use of mobile banking introduced new services such as mobile payments using near-field-technology (NFC) sensors and mobilewallets, where customers can save and use bank cards and merchant loyalty cards.

As we've seen, payments evolved relatively quickly. Below are the many technological advancements that changed traditional payments forever:

\section{a) Automatic Teller Machine (ATM)}

The first ATM was introduced in 1967, and it marked the beginning of the automation era in banking.. The ATM, short for Automated Teller Machine, is a computer device that works with plastic cards such as debit and credit cards with the primary purpose to provide customers with access to services like bank account inquiries, cash withdrawal/deposit and printing bank statements without the need of queuing at a branch for human interaction. ATMs at first were installed solely outside the bank branches, but later, banks realised the value of installing their ATMs in crowded public places like markets and airports. Although ATMs communicate using a safe network, banks ask consumers to be careful while operating them. Security can be compromised with the use of devices such as cameras or scanners that miscreants install in the machines to clone a card or espy the card's PIN.

According to Mr. Scott Talbott, "After the success of chip cards in other countries such as Canada, France, and Australia, chips cards were introduced to the United States in 2015. Chip 
cards fight counterfeit cards used to make purchases in stores. While traditional magstripe cards stored static data, the chip in the card generated a unique code every time the card was used to make a purchase." According to Visa, chip technology has helped reduce in store counterfeit fraud in the U.S. by 76 percent

\section{b) Contactless Payments}

One of the latest developments in payments is contactless. Contactless cards allow consumers to simply tap their cards on the payment terminal in order to pay. Contactless payments provide added convenience and speed to the checkout counter. Customers around the globe are using contactless cards. Apple Pay and Google Pay utilize contactless technology to enable consumers to use their phones to simply tap and pay. This technology was especially important during the COVID pandemic- allowing consumers to avoid contact with common surfaces. Finally, contactless payments also add an important layer of security by using biometrics to authenticate the cardholder.

\section{c) Peer-to-Peer Payments}

Mr. Scott Talbott feels that many Peer to Peer (P2P) applications such as Zelle, Venmo, Apple Pay Cash, PayPal, have steadily over the a few short years provided consumers an easy way to transfer money. While one of the main uses of these applications is to transfer funds between peers, $\mathrm{P} 2 \mathrm{P}$ have morphed to allow merchants to accept payments from their customers. COVID triggered a positive response from consumers utilizing P2P services, which saw a significant increase in both number of users as well as amount of money being moved.

\section{RESEARCH OBJECTIVES}

The primary objective of the study was to explore the role and impact of automation and technology in the banking sector and stock markets.

The secondary objectives, originating from the primary one, were:

- To study the trends of automation in the banking sector and stock markets after computerisation.

- To analyse the technological innovation and advancement in the banking sector.

- To gain an in-depth understanding of the change brought about by automation in these two sectors

The purpose of this study was to get insights to help bankers and stock traders develop effective and efficient strategies focused at enhancing overall customer experience. 


\section{HYPOTHESIS}

Research Hypothesis $\mathbf{H}_{\mathbf{1}}$ - There is a significant difference in costs and customer satisfaction among other variables after implementation of automation and technology in banking sector and stock markets

Null hypothesis $\mathbf{H}_{\mathbf{0}}$ - There is no significant difference in costs and customer satisfaction among other variables after implementation of automation and technology in banking sector and stock markets

\section{RESEARCH METHODOLOGY}

This research paper is based on secondary data collected by extensive literature review through websites, abstracts, peer - reviewed online journals.

For the purpose of this paper, an in-depth study of below 5 financial institutions/companies was conducted.

- ICICI Securities

- National Stock Exchange of India (NSE)

- ICICI Bank

- Axis Bank

- Bank Of America

The thought behind selection of these companies was :

- All are finance and banking related organisations

- Have chosen NSE/BSE for studying role of automation in stock markets as it is India's premier stock exchange

- Banks were selected keeping in mind that at least one is Indian and one multinational.

Data has been collected by studying the websites of these organisations with respect to use of automation and technology in their operations.

\section{DATA COLLECTION}

\subsection{ICICI Securities}

In the below graphs, we can observe that over the course of 6 quarters, the share of digital sourcing in the total client sourcing mix has more than doubled, as a result of improved 
technology and automation, making the use of the service more convenient for the client. This has subsequently led to the decline in need for physical branches.

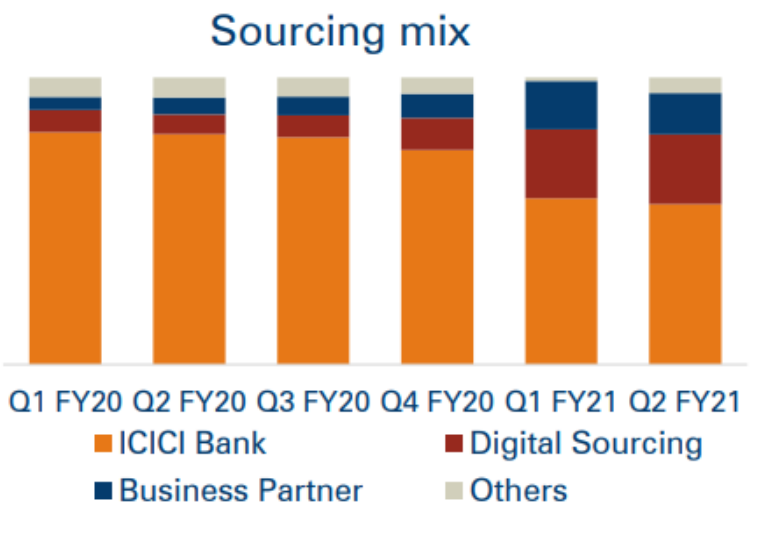

Fig 3 : Proportion of Sourcing Mix for ICICI Bank over 6 quarters.

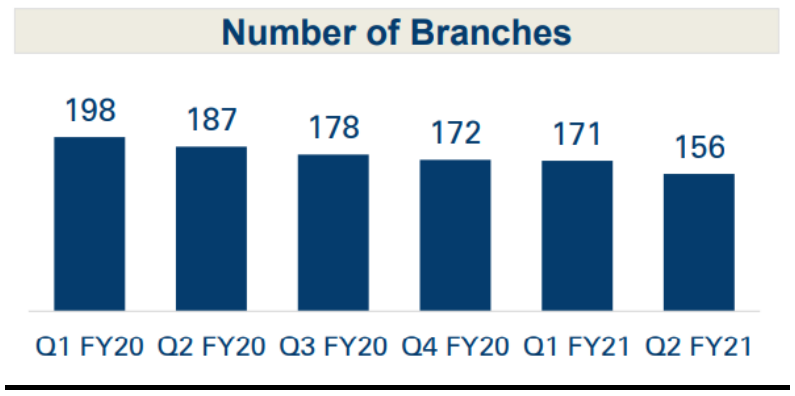

Fig 4 : Number of ICICI Bank Branches over 6 quarters.

\subsection{National Stock Exchange of India (NSE)}

NSE operates on the 'National Exchange for Automated Trading' (NEAT+) system, a fully automated screen based trading system, which adopts the principle of an order driven market. NSE consciously opted in favour of an order driven system as opposed to a quote driven system. This has helped reduce jobbing spreads not only on NSE but in other exchanges as well, thus reducing transaction costs.

\subsection{ICICI Bank}

Robotic Processes Automation has been used in multiple capacities at ICICI Bank, major ones being :- 
Form 15G / 15H : Software robotics has been deployed to perform end-to-end processes involving resolution of queries related to Form $15 \mathrm{G} / 15 \mathrm{H}$. This form is a self-declaration form submitted by an individual for non-deduction of tax on interest income. There are lakhs of such forms that are processed annually in Q1 of the financial year. The activity would take around three days, but with software robotics, the turn-around-time has reduced from three days to same day closure with $100 \%$ accuracy.

ATM query resolution: This is the process of handling ICICI Bank customer queries who have encountered unsuccessful cash withdrawal while using an ICICI Bank ATM. Earlier, the turnaround-time for resolving such queries was seven days. Now, with software robotics, the resolution time has come down to four working hours.

\section{Debit and credit cards}

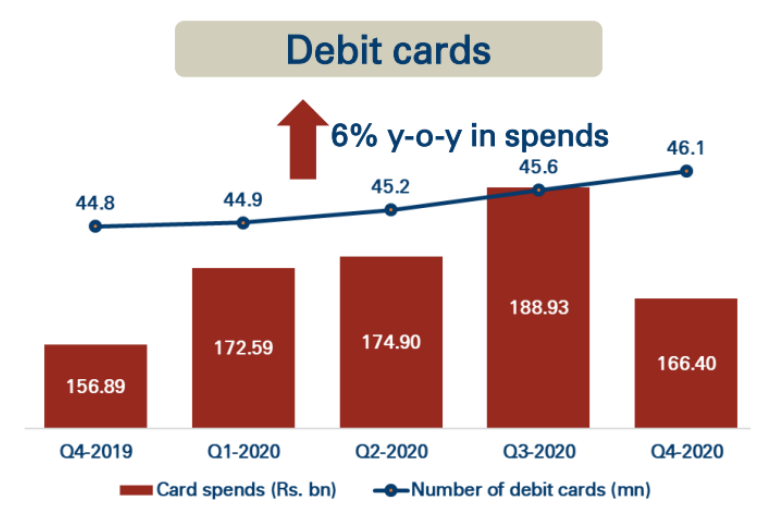

Average spends in Mar 2020 were lower by $22 \%$ compared to the average for Jan and Feb 2020

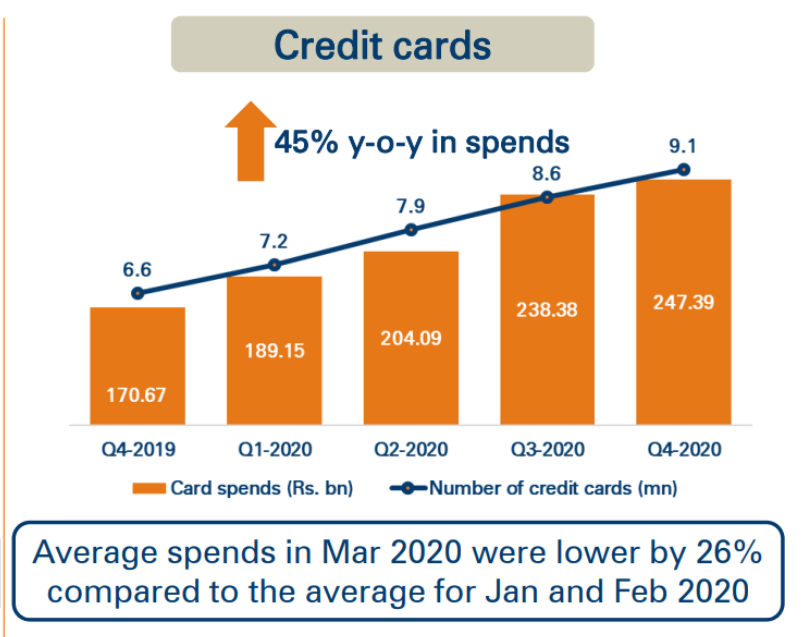

Average spends in Mar 2020 were lower by 26\% compared to the average for Jan and Feb 2020

\section{Fig 5 : Trends in Debit and Credit Card Usage by Customers of ICICI Bank}

Similarly, there are significant time efficiencies that have taken place for many business processes like, mobile number updation for internet banking alerts, ECS presentation for loan repayments, Aadhaar details validation, importer-exporter code validations, debit card reissuance to name a few among many others.

\subsection{Axis Bank}

When savings account onboarding was shifted from walk-in processes to a digital system, the turnaround time (TAT) was reduced by $75 \%$ and the need for physical documents was also abolished. The same holds true for mutual fund trading as well. 
International Journal of Social Science and Economic Research

ISSN: 2455-8834

Volume:06, Issue:07 "July 2021"

- Account opening TAT ${ }^{\wedge}$

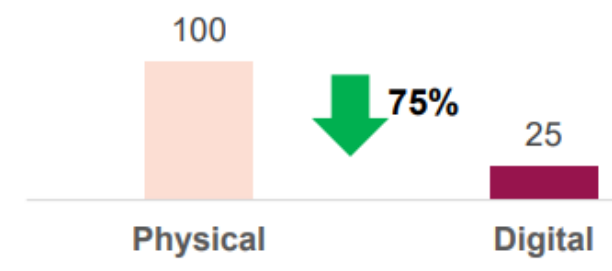

- Physical documents required (in \#)

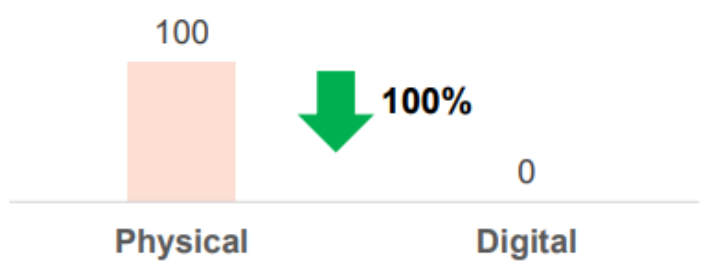

Fig 6: Turnaround Time and Hard Copy of Documents Required for Account Opening at Axis Bank

Cost of customer acquisition fell by as much as $85 \%$ during the shift from physical to digital marketing.

- Cost of acquisition

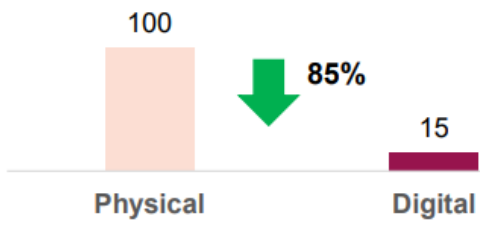

\section{Fig 7 : Cost of Customer Acquisition at Axis Bank}

\subsection{Bank of America}

In the past decade, Bank of America has invested roughly $\$ 25$ billion in new technology initiatives with the aim of creating efficiency and investment for future requirements. The investments were made in the bank's major IT systems and building an internal cloud and software architecture for maximum efficiency and reduced time to market for the bank's products. Part of the reworking is the upgrade of integration across systems and investment in robotic process automation.

Like any other bank in that era, there are numerous functions where decisions are reached through data-intensive processes and highly manual repetitive tasks. The bank prioritised Robotic Process Automation (RPA) as an enabler of business transformation across customer servicing operations, regulatory compliance, and foreign money transactions.

A few of the the stated objectives for deploying RPA were:

- Create a more reliable and consistent experience for customers and clients. 
- Improve transparency with regulators.

- Increase efficiency and speed-to-market of services and products.

- Reduce operational risk.

- Improve and reduce the cost-to-serve customers.

So far, Bank of America has implemented RPA across the following operations, and it intends is to continue to grow the programme:

- Foreign money transaction operations and global payments operations.

- Servicing customers for mortgage and card disputes.

- Salient qualitative benefits include:

- Greater consistency, speed, and accuracy of key processes across mortgage and vehicle servicing.

- Automating dispute resolutions for mortgage disputes on credit reports, as well as credit card disputes, has improved the experience of its customer, and improved operational efficiencies of the department.

Key quantitative benefits include:

- RPA across mortgage and vehicle servicing has reduced the average time taken to service 4,000 cases per month from 20 minutes per case to 4 minutes: This has led to an $89 \%$ reduction in the need for manual reviews.

- Operating hours are far more predictable, and therefore service hours are more manageable, which has led to a reduction in overtime required. 
RPA deployments

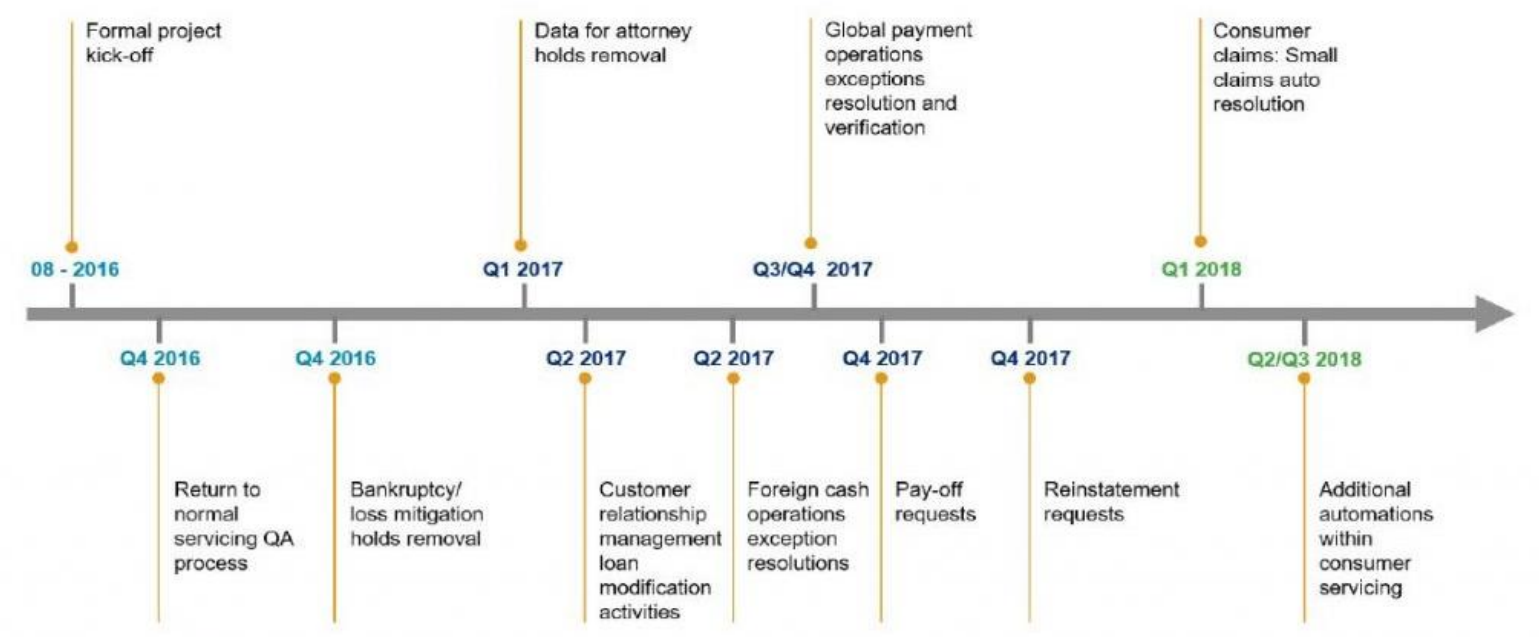

Source: Bank of America, Celent

Fig 8: Robotic Process Automation Functions and their Deployment Timeline at Bank of America.

\section{DISCUSSION}

We are all used to making purchases with our credit, debit or prepaid cards. For many years, this process was relatively straightforward. However, technology, as well as a few other forces, have significantly changed that experience over just a few short years. Technology advancements, the need for convenience, security and regulations have all played a part in causing a significant shift in the way we pay for goods and services. Going way back, cash was the only option available for most purchases. Checks entered the scene and made it possible to carry less cash, make larger purchases and create a lag from when we purchased the goods to when we actually paid for it. Next in the timeline, came the plastic credit and debit cards where just one swipe changed everything and enabled our wallets and purses to shrink but greatly increase our purchasing power.

Another major change to payment methods has been incentives to the customer - rewards. Today merchants and credit card companies offer rewards such as airline miles and cashbacks, to incentivize consumers to use a specific payment method.

Fast forward to today, and the average customer has a wide variety of options to pay when they shop - in store or online. They can use cash, credit card or mobile wallets to pay. They can scan a 


\section{International Journal of Social Science and Economic Research}

ISSN: $2455-8834$

Volume:06, Issue:07 "July 2021"

QR code with their Apple phone to pay or use a peer-to-peer (P2P) application like PayPal or Venmo.

\section{What's Next for Customers and Technology?}

How consumers receive, hold, and spend money is becoming invisible and payments technology providers will continue to look for ways to make it easier, faster, and safer for consumers to conduct their daily transactions. Payment technology has become faster, more secure and fun. Looking forward, technology will continue to play a big role in the evolution of payments and how customers make purchases.

Technology is changing the role of payments as a core banking function, which is already eroding, is now under full assault. Between FinTech firms like Square, big tech wallets and the massive impact of COVID-19, the payment space is being upended as never before.

Payments are the lifeblood for banks and credit unions. Yet this vital source of revenue, data and customer engagement increasingly stands at risk.

"No part of the payments ecosystem will escape the effects of the pandemic," Accenture asserts. The consulting firm predicts that a total of 2.7 trillion transactions worth $\$ 48$ trillion will shift from cash to cards, interbank payments and alternative payment instruments such as person-toperson (P2P) and point-of-sale finance (buy now, pay later). This represents a $\$ 300$ billion opportunity for payment providers. However, Accenture states that banks are scrambling to respond as the scale of disruption and tempo of change have grown dramatically.

All is not gloom and doom, however. Incumbents still have significant advantages of scale and trust, particularly since the risk of fraud has jumped sharply in an increasingly digital payment environment. But the need to modernize legacy payments infrastructure has never been more important for traditional institutions. "Reimagining the post-COVID world in payments could offer new opportunities to reignite performance," observes Zachary Aron, U.S. Banking \& Capital Markets Payments Leader for Deloitte Consulting.

In the seven trends below, the scope of the challenge is presented, along with advice on how to meet it in the year ahead, including a further-out development that could be transformational for payments at many levels.

\section{Trend 1: Digitization, E-Commerce and Changed Payment Habits}

Spurred by the pandemic, consumers shifted their buying habits from in-person to e-commerce channels - not totally of course, but significantly. Black Friday shopping numbers, for example, showed in-store traffic down by half from 2019 with online spending up $22 \%$. 
International Journal of Social Science and Economic Research

ISSN: 2455-8834

Volume:06, Issue:07 "July 2021"

Even before the holiday spending season, the number of consumers who make half or more of their monthly purchases via e-commerce nearly doubled during the pandemic, according to Capgemini research conducted in August 2020. In addition, consumers expect the transition from retail to e-commerce will continue even after the virus has been contained.

"The prevailing COVID 19 environment catalyzed a cross-generational shift toward digital channels and digital payment methods," Capgemini states. "Even Baby Boomers (aged 56 and over) said they made payments through digital channels a lot more during the lockdown, emerging as late majority adopters."

The firm also found that nearly two thirds (64\%) of consumers said they had used contactless cards during the pandemic. $41 \%$ of consumers said they used contactless cards for the first time during the crisis.

"The longer term impacts of the use of 'touchless payment' solutions may be the biggest impact of COVID-19," states Margaret Weichert, who leads Accenture's North American Payments Practice. "In addition to contactless chip cards," she adds, "consumers and merchants are exploring a range of new solutions, including 'in-aisle' checkout, QR code scan solutions and completely contactless solutions like Amazon Go stores."

The QR code payment statistics shown in the above two charts are based on worldwide data and thus are impacted by heavy use of this form of mobile payment in the Asia-Pacific region. Interest in the U.S. is picking up, however. A survey by Mercator Advisory Group reported an $11 \%$ increase in QR payment use in the U.S. through October 2020. PayPal, Square and UberEats have all introduced QR code payments capability.

\section{Trend 2: Incumbents Face Big Payment Revenue Squeeze}

Payments attract many players because it can be a lucrative business. McKinsey plotted total shareholder returns for four industry segments involved in payments worldwide.

Unfortunately for traditional financial institutions - historically the main providers of payments services - the rising returns shown above do not extend to most of them, McKinsey observes. That's because traditional payment revenue sources have been hammered by low interest rates, higher credit-card losses and pressure on interchange and other payment fees due to regulation and competition. The firm does not see a near-term improvement in this picture.

All this points to a quandary for banks and credit unions in the payments business. The "cost of ownership" of payments services, as McKinsey puts it, will remain high, leaving little to invest in new products to improve customer experience. Yet the need to do so is growing. 
International Journal of Social Science and Economic Research

ISSN: 2455-8834

Volume:06, Issue:07 "July 2021"

\section{Trend 3: Disruption Accelerates - Credit Cards at Risk from 'BNPL'}

The payments business has been "disrupting" long before the term became a buzzword in the FinTech era. But even though many of the earlier disruptions turned out to be more like evolutions than revolutions (like the disappearing checks that didn't, or the glacial uptake, until recently, of mobile wallets), all the sources tapped for this article agreed that payments disruption has picked up dramatically in 2020 and will continue.

The U.S. is one of the countries most susceptible to this transformation, according to Accenture. The firm even created a "Payments Disruptibility Index" in a new report. It points to credit cards as the payments segment with the highest susceptibility to disruption. The primary cause: Pointof-sale lending, also known as "buy now pay later" (BNPL).

These solutions, pioneered by FinTechs such as Affirm, Klarna and Afterpay, enable consumers to select a credit card or installment plan either at the time of purchase or in some cases, such as with Chase's My Chase Plan, after the purchase. These plans typically charge only a flat fee.

Debit cards are not immune from disruption. On one hand, they have benefitted from consumers' decreased use of credit, in an effort to stay out of debt during the recession. On the other hand, they are becoming increasingly vulnerable to disruption from person-to-person (P2P) transactions which have grown rapidly during the pandemic and are being used more often to pay for services previously paid for by card. "Peer-to-peer schemes have seen growing adoption and more diverse uses," notes BCG. "App downloads for Square, Zelle, Venmo, and PayPal all rose by more than 50\% in April and May 2020, compared with the year before," the firm states.

\section{Trend 4: B2B Payments in FinTechs' Sights}

While corporate payments and trade finance have seen much less disruption so far, due to the complexity of these transactions, FinTech entry into the small and mid-size business payment market is now in full swing. FinTechs, after all, thrive on reducing complexity and small businesses need all the help they can get.

"New-wave FinTech are eager to take on more B2B functions," says Capgemini. "Firstgeneration FinTech disrupted the front-end of the retail payments value chain and assertively stepped into cross-border payments, invoice discounting, and SMB financing. Now, they are targeting pivotal B2B middle- and back-office functions." The consulting firm mentions several: Dutch company Adyen, U.S. based Stripe, the U.K. 's Rapyd and Iwoca among them. Not to mention U.S. powerhouse Square, rapidly expanding its scope as indicated by its QR code announcement mentioned above. 
International Journal of Social Science and Economic Research

ISSN: 2455-8834

Volume:06, Issue:07 "July 2021"

\section{Trend 5: Big Techs on the Prowl in Payments}

"Google and Facebook have made no secret that they see payments as a means to gain a foothold into growing markets," Capgemini observes. While some of their most advanced efforts to date have been targeted at overseas markets (Facebook's WhatsApp Pay launch in India, for example) activity in the U.S. is also moving forward rapidly.

"Payments are a gateway for big tech firms to encroach further into the financial services landscape." says Capgemini.

Google updated and expanded its Google Pay digital wallet in the fall of 2020. In addition, the wallet incorporates the company's new GooglePlex checking and savings product offered in conjunction with a growing list of banks and credit unions, with Citibank topping the list.

"Payments are a gateway for big tech firms to encroach further into the financial services landscape," Capgemini maintains.

\section{Trend 6: Further Ahead - Digital Currencies and Distributed Ledger Technology Will Reshape Payments}

It may be several years before digital currency ecosystems reach critical mass, according to BCG, but much is already happening with several central banks planning to introduce their own digital coins and tokens. Then, too, Facebook is moving forward with its digital currency Libra, planning to launch a dollar-backed digital Libra coin in the U.S. and several other markets, along with its Novi digital wallet.

Already several banks have introduced stablecoins (digital currencies pegged to a stable asset, like the dollar) for business payment use - notably New York's Signature Bank, along with JPMorgan Chase.

\section{Trend 7: Modernization, Collaboration and Other Ways Forward}

More than four out of five banking executives in North America surveyed by Accenture agree that transforming the payments business is a key element of their broader digital transformation efforts. In fact, many have invested in multi-year payments modernization programs. The problem is that most of these investments are not driven by customer needs, but by compliance or governmental factors, which results in a poor return on investment. Some solutions, such as switching to cloud providers, bring benefits, but more is needed to compete in the kind of environment described above.

\section{CONCLUSION}


International Journal of Social Science and Economic Research

ISSN: 2455-8834

Volume:06, Issue:07 "July 2021"

Based on the data collected and its analysis, we can conclude that there is a significant reduction in monetary and human capital expenditure after implementation of automation and technology in banking sector and stock markets, hence reinforcing the research hypothesis. The presented insight will help bankers and stock traders develop effective and efficient strategies focused at enhancing overall customer experience as well as improve profitability. Thus, the Research Hypothesis $\left(\mathbf{H}_{\mathbf{1}}\right)$ is accepted and the Null Hypothesis $\left(\mathbf{H}_{\mathbf{0}}\right)$ is rejected.

\section{LIMITATIONS AND FUTURE SCOPE}

The limitations faced for the research undertaken for this paper were Study Design Limitations. Since this study is exploratory in nature and based primarily on secondary research, it is not definitive, though it provides ample insights to base future research on.

\section{ACKNOWLEDGEMENTS}

I would like to sincerely thank Mr. Scott Talbott, Senior Vice President of Government Affairs at the Electronic Transactions Association (ETA), for his contribution to this paper, specifically Review of Literature and Discussion sections. In 2010, he appeared in the Oscar-winning film, 'Inside Job'. Mr. Talbott's experience of almost three decades in significant roles such as Chief Lobbyist and Executive Vice President of Public Policy for the Financial Services Roundtable, expertise in the financial services and FinTech industries, insights and encouragement greatly assisted my research.

I am greatly indebted to Mr Sumer Broota, my mentor at the Pratham Team, for his guidance and encouragement all throughout the process of writing this research paper.

\section{REFERENCES}

[1] Technology definition and meaning: Collins English Dictionary. (n.d.). Retrieved July 19, 2021, from

https://www.collinsdictionary.com/dictionary/english/technology

[2] Amadeo, K. (2021, March 22). What is banking? Retrieved July 19, 2021, from https://www.thebalance.com/what-is-banking-3305812

[3] Chen, J. (2021, March 06). Stock market. Retrieved July 19, 2021, from https://www.investopedia.com/terms/s/stockmarket.asp

[4] Basics of Stock Exchange (2020, December 28). What is a stock exchange ? Retrieved July 19, 2021, from 


\section{International Journal of Social Science and Economic Research}

ISSN: $2455-8834$

Volume:06, Issue:07 "July 2021"

https://www.bloombergquint.com/financial-terms/what-is-stock-exchange-definition-meaningand-basics-of-stock-exchange

[5] Latimore, D. (2019, November 05). Case study on Bank of America: How robots help serve and protect the bank. Retrieved July 19, 2021, from

https://www.fintechfutures.com/2019/11/case-study-on-bank-of-america-how-robots-helpserve-and-protect-the-bank/

[6] Oxford learner's Dictionaries. (n.d.). Retrieved July 19, 2021, from https://www.oxfordlearnersdictionaries.com/

[7] What is Automation? (n.d.). Retrieved July 19, 2021, from https://www.isa.org/about-isa/what-is-automation

[8] Thierer, A. (2020, June 14). Defining "technology". Retrieved July 19, 2021, from https://techliberation.com/2014/04/29/defining-technology/

[9] Raval, A. (2019, July 16). ICICI bank moving into complex Automation, COMBINING RPA, OCR and AI, ML. Retrieved July 19, 2021, from https://www.expresscomputer.in/rpa/icici-bank-moving-into-complex-automation-combiningrpa-ocr-and-ai-ml/37814/

[10] Evolution of Banking Technology. (2020, September 23). Retrieved June 10, 2021, from https://www.usbank.com/financialiq/manage-your-household/personal-finance/evolution-ofbanking-technology.html

[11] The Past and Future of Automation in Banking (2019, November 6). Retrieved from https://automationacademy.com/en/blog/past-and-future-automation-banking-sector

[12] Cliff, D., Brown, D., \& Treleaven, P. (2011). Technology Trends in the Financial Markets: A 2020 Vision. UK Government Office for Science.

http://www.bis.gov.uk/assets/bispartners/foresight/docs/computer-trading/11-1222-dr3technology-trends-in-financial-markets.pdf

[13] Mayor, T. (2021, February 04). Fintech, explained. Retrieved June 11, 2021, from https://mitsloan.mit.edu/ideas-made-to-matter/fintech-explained

[14] ICICI Bank Performance Review Q4 2020. (2020, May).

https://www.icicibank.com/managed-assets/docs/investor/quarterly-financialresults/2020/ICICI-Bank-Investor-Presentation-on-Performance-Review-Q4-2020 [Pdf].

[15] National Stock Exchange of India Homepage (n.d. ). Retrieved June 10, 2021, from 
International Journal of Social Science and Economic Research

ISSN: 2455-8834

Volume:06, Issue:07 "July 2021"

nseindia.com

[16] ICICI Securities Website (n.d. ). Retrieved June 10, 2021, fromhttps://www.icicisecurities.com/

[17] Mayor, T. (2021, February 04). Fintech, explained. Retrieved June 11, 2021, from https://mitsloan.mit.edu/ideas-made-to-matter/fintech-explained

[18] Axis Bank Digital Banking Presentation (2020, December). Retrieved May 31, 2021, from https://www.axisbank.com/docs/default-source/investor-presentations/digital-banking-

presentation-dec-2020.pdf 